\title{
Article \\ Cytological and Molecular Characterization for Ploidy Determination in Yams (Dioscorea spp.)
}

\author{
Cobes Gatarira ${ }^{1,2}$, Lucia Sládeková ${ }^{3}$, Alžběta Němečková $^{3} \oplus$, Denisa Šimoníková ${ }^{3} \oplus$, Rajneesh Paliwal ${ }^{1}$,

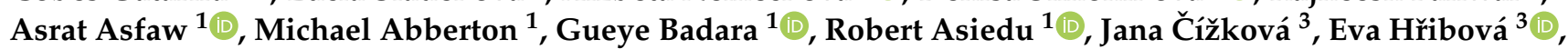

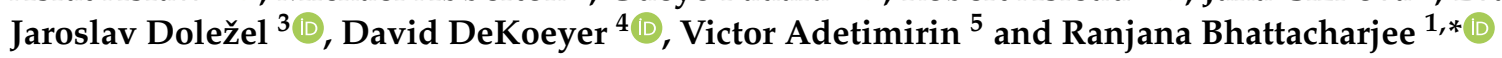

1 International Institute of Tropical Agriculture, Ibadan 200001, Nigeria; cobesgatarira@gmail.com (C.G.); R.Paliwal@cgiar.org (R.P.); a.amele@cgiar.org (A.A.); M.Abberton@cgiar.org (M.A.); B.Gueye@cgiar.org (G.B.); r.asiedu@cgiar.org (R.A.)

2 The Pan African University Institute of Life and Earth Sciences, University of Ibadan, Ibadan 200132, Nigeria

3 Institute of Experimental Botany of the Czech Academy of Sciences, Centre of the Region Hana for Biotechnological and Agricultural Research, Šlechtitelů 31, CZ-77900 Olomouc, Czech Republic; lucia.sladekova01@upol.cz (L.S.); nemeckova@ueb.cas.cz (A.N.); simonikova@ueb.cas.cz (D.Š.); cizkova@ueb.cas.cz (J.Č.); hribova@ueb.cas.cz (E.H.); dolezel@ueb.cas.cz (J.D.)

4 Fredericton Research and Development Centre, Agriculture and Agri-Food Canada, P.O. Box 20280, Fredericton, NB E3B 4Z7, Canada; david.dekoeyer@canada.ca

5 Department of Crop and Horticultural Sciences, University of Ibadan, Ibadan 200132, Nigeria; votimirin@yahoo.com

check for updates

Citation: Gatarira, C.; Sládeková, L.; Němečková, A.; Šimoníková, D.;

Paliwal, R.; Asfaw, A.; Abberton, M.; Badara, G.; Asiedu, R.; Č́́žková, J.; et al. Cytological and Molecular Characterization for Ploidy Determination in Yams (Dioscorea spp.). Agronomy 2021, 11, 1897. https://doi.org/10.3390/agronomy 11101897

Academic Editor: Peter Langridge

Received: 12 July 2021

Accepted: 15 September 2021

Published: 22 September 2021

Publisher's Note: MDPI stays neutral with regard to jurisdictional claims in published maps and institutional affiliations.

Copyright: (c) 2021 by the authors. Licensee MDPI, Basel, Switzerland. This article is an open access article distributed under the terms and conditions of the Creative Commons Attribution (CC BY) license (https:// creativecommons.org/licenses/by/ $4.0 /)$.
* Correspondence: r.bhattacharjee@cgiar.org

Abstract: Yam (Dioscorea spp.) is a monocotyledonous herbaceous vine plant grown in the tropics and subtropics. It is a multi-species plant with varied intra- and interspecific ploidy levels. Of the 600 species, 11 are cultivated supporting the livelihood of over 300 million people. The paucity of information on ploidy and the genomic constitution is a significant challenge to the crop's genetic improvement through crossbreeding. The objective of this study was to investigate the ploidy levels of 236 accessions across six cultivated and two wild species using chromosome counting, flow cytometry and genotyping-based ploidy determination methods. Results obtained from chromosome counting and genotyping-based ploidy determination were in agreement. In majority of the accessions, chromosome counting and flow cytometry were congruent, allowing future rapid screening of ploidy levels using flow cytometry. Among cultivated accessions, 168 (71\%) were diploid, $50(21 \%)$ were triploid, and $12(5 \%)$ were tetraploid. Two wild species included in the study were diploids. Resolution of ploidy level in yams offers opportunities for implementing successful breeding programmes through intra- and interspecific hybridization.

Keywords: flow cytometry; chromosome counting; ploidy level; DArTseq

\section{Introduction}

Yam (Dioscorea spp.) is a monocot herbaceous vine plant grown in the tropical and subtropical regions of the globe. There are about 600 species of yams of which only eleven are edible and economically significant viz. D. alata (water or greater yam), D. rotundata (white Guinea yam), D. cayenensis (yellow guinea yam), D. dumetorum (trifoliate or bitter yam), D. bulbifera (aerial yam), D. esculenta (lesser yam), D. polystachya (Chinese yam), D. japonica (East Asian mountain yam, yamaimo, or Japanese mountain), D. pentaphylla (five-leaf yam), D. nummularia (Pacific yam), and D. trifida (Cush Cush, Indian, or sweet yam) [1-3]. Yam produces starchy underground tubers and ariel bulbils that provide dietary nutrients such as starch, protein, vitamins, and micro-nutrients for those who depend on it as a staple food [4]. In West Africa, yam is a highly priced tuber crop contributing about $15 \%$ of the daily per capita calorie intake and about $32 \%$ farm income for over 300 million people [5]. West Africa represents over $90 \%$ of global yam production [6]. Although yam production 
in Africa is $40 \%$ lower than that of cassava, its gross economic value exceeds that for all other African staple crops and is equivalent to the summed value for maize, sorghum, and rice, the top three cereal crops [6].

Notwithstanding its high value, yam productivity in West Africa is low and has remained stagnant over the last two decades [3]. The low productivity is attributed to a combination of biotic (yam anthracnose, virus, and nematodes) and abiotic (poor soil fertility and drought) factors, as well as underdeveloped agronomic practices and poorquality planting materials $[3,4,7,8]$.

Development and deployment of resilient varieties tolerant to biotic and abiotic stresses which meet consumer preferences offer opportunities to ameliorate the challenges to yam cultivation. However, varietal development in yam has been slow due to a combination of biological constraints such as non or erratic flowering, non-synchronous flowering, dioecy, polyploidy, high heterozygosity, long growth cycle, and vegetative propagation with a low multiplication ratio [9-11]. Yam improvement programmes mainly involves clonal selection impeding speedy genetic progress due to lack of combination of desirable characteristics in a single variety. Therefore, significant yam improvement will need to go through sexual reproduction for combining desirable characteristics. However, the challenges to intra- and interspecific hybridization in yam are mostly related to ploidy level differences, which result in incompatibility, thus preventing the successful transfer of genes because the progeny generation may be partially sterile $[3,12,13]$. Darkwa et al. [3] reported that the average percentages of fruit and seed sets are $20.3 \%$ and $10.5 \%$ in D. rotundata, with corresponding values of $28 \%$ and $9.3 \%$ in D. alata crossing blocks, respectively. The authors attributed the low success of cross-pollination and hybrid progeny generation partly to differences in ploidy level between the parents used in crosses. Several authors reported the occurrence of diploids $(2 n=2 x=40)$; triploids $(2 n=3 x=60)$ and tetraploids $(2 \mathrm{n}=4 \mathrm{x}=80)$ in yam [14-16]. The ploidy level differences limit the choice of parents to cross in producing desirable hybrids that are superior to the currently grown cultivars. It is therefore necessary to establish basic knowledge about yam genetic resources, especially the ploidy status for successful yam improvement program.

Polyploidy have distinctly played a significant role in the speciation and evolution of both cultivated and wild plants [17]. Some of the major advantages of polyploidy for plant breeding has been increased vigour, buffering of deleterious mutations, increased heterozygosity, and heterosis (hybrid vigour), in some cases, better than the diploid relatives. The existence of yams with different ploidy levels offers a magnificent system to investigate the impact of ploidy levels on productivity traits to accelerate yam breeding programs. Several studies on polyploidy in yams have correlated with growth vigour, higher tuber yield and increased tolerance to abiotic and biotic stress [18,19]. Attempts have also been made through conventional hybridization to generate intra- and interspecific hybrids specifically among and between $D$. rotundata, D. alata, D. cayenensis and D. bulbifera using different combinations [personal communication]. However, there was no success in producing viable hybrids in interspecific crosses, and in several of the intraspecific crosses, sterility among the progenies was observed $[3,17]$. Therefore, all yam breeding programmes exclusively produce diploid varieties. In addition, there is a lack of information available on ploidy status of germplasm collections across all Dioscorea spp. Ploidy determination in yam accessions would therefore facilitate the planning and execution of successful breeding strategies through intra- and interspecific hybridization. For example, breeding in roses is facilitated through careful selection of individuals that produce gametes of similar ploidy level to circumvent restrictions or barriers caused by dissimilar ploidy levels between plants [20].

Several methods have been used to estimate ploidy levels in crops [21], the most common among which are chromosome counting and flow cytometry. The flow cytometry technique has been used for determining the ploidy levels of various plant species, including yams [15,22-26]. The method offers numerous advantages such as non-destructive, analyses of interphase nuclei, and sample preparation from a small amount of tissues (mg). 
Furthermore, the analysis of large populations of interphase nuclei makes it possible to identify sub-populations differing in DNA amounts and hence recognize mixoploids. In addition, the simplicity, speed, and convenience allow the analysis of many samples in a single day [23-26]. Flow cytometry, however, analyses nuclear DNA content and not the number of chromosomes, making reliable ploidy screening possible only within a species. Flow cytometry also requires a reference plant with a known ploidy level as a standard for calibration.

A chromosome counting technique gives accurate ploidy status of an organism and has therefore been used to confirm the ploidy levels obtained from flow cytometry. It is, however, laborious, with limitations on the number of cells that can be analyzed within a given time and may be prone to errors when chromosomes are small, as in the case of yams. Researchers have demonstrated that genotyping using molecular markers such as SSRs or next-generation sequencing can be used to assign ploidy level, and these levels are generally consistent with flow cytometry [27-29]. Therefore, use of molecular genotyping data is another option for analyzing ploidy levels, which has not been widely explored in yam $[30,31]$.

Diversity Array Technology (DArT) has become one of the cheap and efficient genotypingby-sequencing platforms characterized by high call rates and scoring reproducibility that has been applied in polyploids such as potato [32] and yams [33]. DArTseq was used in the present study to assess if genotyping data will be useful for assigning ploidy levels to yam accessions representing variable cytotype across different species. It was hypothesized that, with the availability of thousands of bi-allelic single nucleotide polymorphisms (SNPs) and short sequences across the genome, the rates of heterozygosity, allelic ratios, and multi-SNP haplotype counts would differ among accessions, and this information could be harnessed to assign ploidy levels to individual accessions. This approach will reduce the need for flow cytometry and chromosome counting or could be used as a confirmation tool in ploidy assessments in yams.

The objective of this study was to (i) evaluate the ploidy levels of commonly cultivated species of yam and few of their wild relatives; (ii) assess results from chromosome counting and flow cytometry methods with single nucleotide polymorphism (SNP)-genotyping data for consistency; and (iii) identify reference standards for routine ploidy analysis using flow cytometry.

\section{Materials and Methods}

\subsection{Plant Materials}

A total of 236 accessions representing eight Dioscorea spp. was used in this study. These included six cultivated species viz. D. rotundata (119 accessions) representing 52 accessions from Togo, 51 accessions from Nigeria, and remaining accessions from Ghana, Benin and Cote d'Ivoire; D. alata (82 accessions) representing 44 accessions from Togo, 14 accessions from Benin, 12 accessions from Nigeria and remaining accessions from Ghana and Cote d'Ivoire; D. cayenensis (4 accessions) representing one accession each from Togo, Benin, Nigeria and Cote d'Ivoire; D. dumetorum (6 accessions) representing four accessions from Nigeria and two from Togo; D. esculenta (3 accessions) representing two accessions from Togo and one accession from Nigeria; and D. bulbifera (16 accessions) representing seven accessions from Nigeria and remaining accessions from Togo, Benin, Gabon, Congo, Guinea and Sierra Leone; and two wild species namely D. praehensilis ( 1 accession) and D. abyssinica (5 accessions, all collected from Benin) (Table S1). The geographical origin of one accession each of D. rotundata, D. alata and D. prahensilis is unknown. Additional information about these accessions can be accessed online (genesys-pgr.org/c/yam accessed on 2 February 2019). All accessions were obtained as tubers from the Genetic Resources Center (GRC) of the International Institute of Tropical Agriculture (IITA), Ibadan, Nigeria. The tubers were shipped to the Centre of Plant Structural and Functional Genomics, Institute of Experimental Botany (IEB), Olomouc, Czech Republic, where they were planted in the 
greenhouse to generate samples for ploidy analysis by chromosome counting and flow cytometry.

\subsection{Chromosome Counting}

Mitotic metaphase spreads were prepared using the dropping technique according to Dolezel et al. [34]. Actively growing yam roots were collected into $50 \mathrm{mM}$ phosphate buffer with $0.2 \%$ mercaptoethanol. The collected roots were pre-treated in $0.05 \%$ 8-hydroxyquinoline for three hours at room temperature and fixed in 3:1 ethanol: acetic acid at $4{ }^{\circ} \mathrm{C}$ overnight. Fixed roots were washed using $75 \mathrm{mM} \mathrm{KCl}$ and $7.5 \mathrm{mM}$ EDTA solution ( $\mathrm{pH}$ 4). Meristem tips were cut off and digested for $90 \mathrm{~min}$ at $37^{\circ} \mathrm{C}$ using a mixture of $2 \%$ pectinase and $2 \%$ cellulase in $75 \mathrm{mM} \mathrm{KCl}$ and $7.5 \mathrm{mM}$ EDTA solution (pH 4). The protoplast suspension was filtered through a $150 \mu \mathrm{m}$ nylon mesh and pelleted. The pellets were then re-suspended in $75 \mathrm{mM} \mathrm{KCl}$ and $7.5 \mathrm{mM}$ EDTA solution (pH 4), and thereafter incubated for $5 \mathrm{~min}$ at room temperature. After pelleting, the protoplasts were washed three times with $70 \%$ ethanol and stored in $70 \%$ alcohol at $-20{ }^{\circ} \mathrm{C}$ until use.

Five microliters of suspension were dropped onto a slide. Shortly before drying out, $7 \mu \mathrm{L}$ of 3:1 fixative were added to the drop to induce protoplast bursting. Finally, the slide was rinsed in $100 \%$ ethanol and air-dried. The preparations were stained with DAPI (4',6-diamidino-2-phenylindole) and mounted in Vectashield (Vector Laboratories). These were examined with an Axio Imager Z2 microscope (Carl Zeiss, Oberkochen, Germany) equipped with a Cool Cube 1 (Metasystems, Altlussheim, Germany) camera, and images were prepared with ISIS 5.4.7 (Metasystems).

\subsection{Flow Cytometry}

Flow cytometry was performed following the protocol described by Dolezel et al. [34]. About $30 \mathrm{mg}$ of young leaf tissue was chopped with a razor blade in a glass Petri dish containing $500 \mu \mathrm{L}$ Otto I solution ( $0.1 \mathrm{M}$ citric acid, $0.5 \% v / v$ Tween 20) [35]. The crude homogenate was filtered through a $50 \mu \mathrm{m}$ nylon mesh. Chicken red blood cell nuclei (CRBC), prepared according to the methodology described by Galbraith et al. [36], were added to the suspension of yam nuclei as an internal reference standard. After $30 \mathrm{~min}$ incubation on ice, $1 \mathrm{~mL}$ Otto II solution $\left(0.4 \mathrm{M} \mathrm{Na}_{2} \mathrm{HPO}_{4}\right)$ [35] supplemented with $5 \mu \mathrm{M}$ DAPI was added. The samples were analyzed using Partec PAS (Partec GmbH, Münster, Germany) or Sysmex-Partec CyFlow (Sysmex Partec GmbH, Görlitz, Germany) flow cytometers equipped with UV excitation and detectors for DAPI fluorescence. The gain of the instrument was adjusted so that the peak of the CRBC nuclei was positioned approximately at channel 100 on a 512-channel scale. Relative nuclear DNA content of yam accessions was then determined by comparing peak positions of CRBC nuclei and nuclei of the sample. Ploidy level was determined based on the ratio of G1 peak position obtained for a yam accession and CRBC nuclei.

\subsection{DNA Extraction and Quantification}

The tubers of 230 accessions of cultivated Dioscorea spp. were planted at IITA, Ibadan, Nigeria $\left(07^{\circ} 29.299^{\prime \prime} \mathrm{N}, 003^{\circ} 53.186^{\prime \prime} \mathrm{E}\right.$ and $224 \mathrm{~m}$ altitude) during the 2018 cropping season. Fresh yam leaf samples from all accessions were collected in perforated paper pouches and placed on ice. Thereafter, the samples were lyophilized using the LABCONCO freeze dryer (Labconco Corporation, Kansas City, MO, USA). Genomic DNA was extracted from the lyophilized samples using a modified cetyl trimethyl ammonium bromide (CTAB) DNA extraction protocol described by Porebski et al. [37] with some modifications. The quantity of DNA extracted was estimated by comparison with Lambda $(\lambda)$ DNA marker standard using $0.8 \%$ agarose gel electrophoresis and Nanodrop 8000 spectrophotometer (Thermo Fisher Scientific Inc., Wilmington, DE, USA). 


\subsection{Analysis of Molecular Data Using DArTseq SNP Markers}

Genotyping was carried out at Diversity Array Technology (DArT) Pty Ltd., Canberra, Australia, using DArTseq ${ }^{\mathrm{TM}}$ technology (https:/ / www.diversityarrays.com/technologyand-resources/dartseq/ accessed on 2 February 2019). Next-generation sequencing method was used by running the sequencing in the Illumina HiSeq-2500 instrument (Illumina Inc., San Diego, CA, USA). FASTQ raw sequenced data of each sample were processed using a proprietary DArT P/L analytical pipeline (Diversity Array Technology, Canberra, Australia) to filter out poor quality sequences [38]. The processed sequence data were used in another secondary pipeline (DArTsoft14) to generate SNP calling and its alignment on the reference genome of D. rotundata (Yam_drotundata_chr_v01). The SNP calling CSV file of a total of 82,587 SNPs, provided by DArTseq Pvt Ltd. (https:/ /www.diversityarrays.com/productsand-services/information-technology /lims-at-dart-dartdb/ accessed on 12 May 2019), was used to further filter for call rate $(\geq 70 \%)$ and average reproducibility of marker (the proportion of technical replicate assay pairs for which the marker score is consistent; $\geq 95 \%$ ), MAF ( $>0.01)$ and missing data ( $\geq 50 \%)$ using R-program and TASSEL v.5.2.37 software [39].

Genotyping based on the analysis of SNPs was used as previously described by Gompert and Mock [40] to differentiate diploid, triploid and tetraploid genotypes based on allelic ratios and heterozygosity deduced from DArTseq data. The methodology assumes that genotypes with higher ploidy levels should be heterozygous and represent high allelic ratios. For heterozygous bi-allelic SNPs, the diploid genotypes must harbor one copy of each allele (allelic ratio $=1: 1$ ); likewise, triploids must harbor a copy of one allele and two copies of the other or vice versa (allelic ratios $=1: 2$ or 2:1), and tetraploids should harbor different allelic ratio such as one, two or three copies of each allele (allelic ratio of 2:2, 1:3 or 3:1) [31]. Genetic similarity matrix was calculated between each accession using PLINK (v1.90) [41,42] based on the filtered SNPs across 230 accessions of cultivated Dioscorea spp. A maximum likelihood phylogenetic tree was constructed with 1000 bootstraps using MEGA6 [43]. Species-specific SNPs were further used to assess the genetic relationship among the accessions across different species and their ploidy levels using a neighborjoining method with a R-package [44].

\section{Results}

\subsection{Ploidy Estimation Using Chromosome Counting}

The chromosome counting results regarding the ploidy level were similar to DArTseq, except for accessions of two wild species for which DArTseq data were not generated (Table S1). Of the 230 accessions analysed using both chromosome counting and DArTseq genotyping, $168(71 \%)$ were diploid $(2 \mathrm{n}=2 \mathrm{x}=40), 50(21 \%)$ were triploid $(2 \mathrm{n}=3 \mathrm{x}=60$, and $12(5 \%)$ were tetraploid $(2 n=4 x=80)$ (Figure 1; Table S1). Figure 2 represents few examples of the results from chromosome counting wherein TDr2763 was found to be a diploid with $2 n=2 x=40$, TDa1030 and TDd 3778 were triploids with $2 n=3 x=60$, while TDes3038 was a tetraploid with $2 n=4 x=80$. 


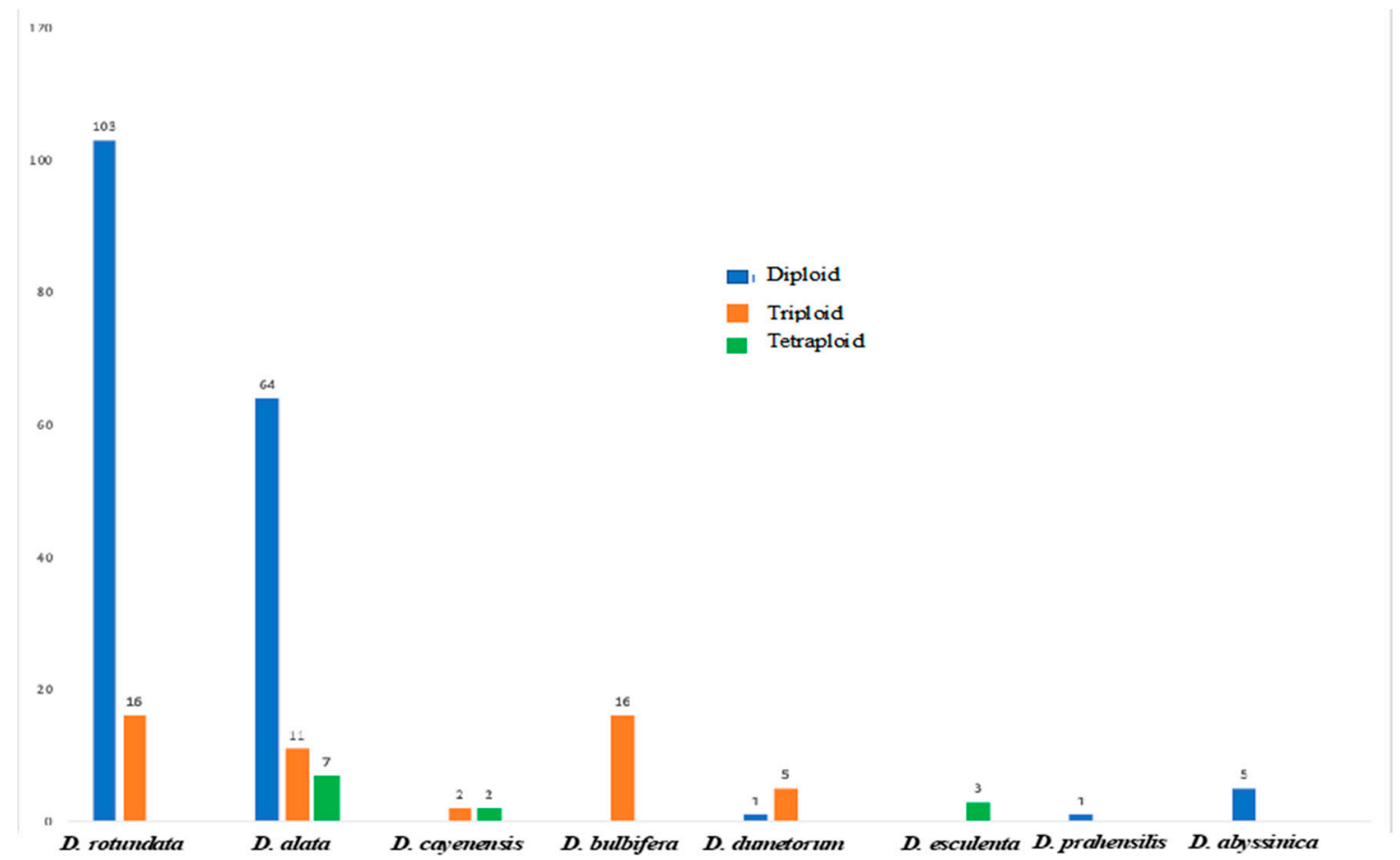

Figure 1. Ploidy levels determined by chromosome counting and DArTseq analysis in six cultivated Dioscorea spp., and chromosome counting in two wild species.
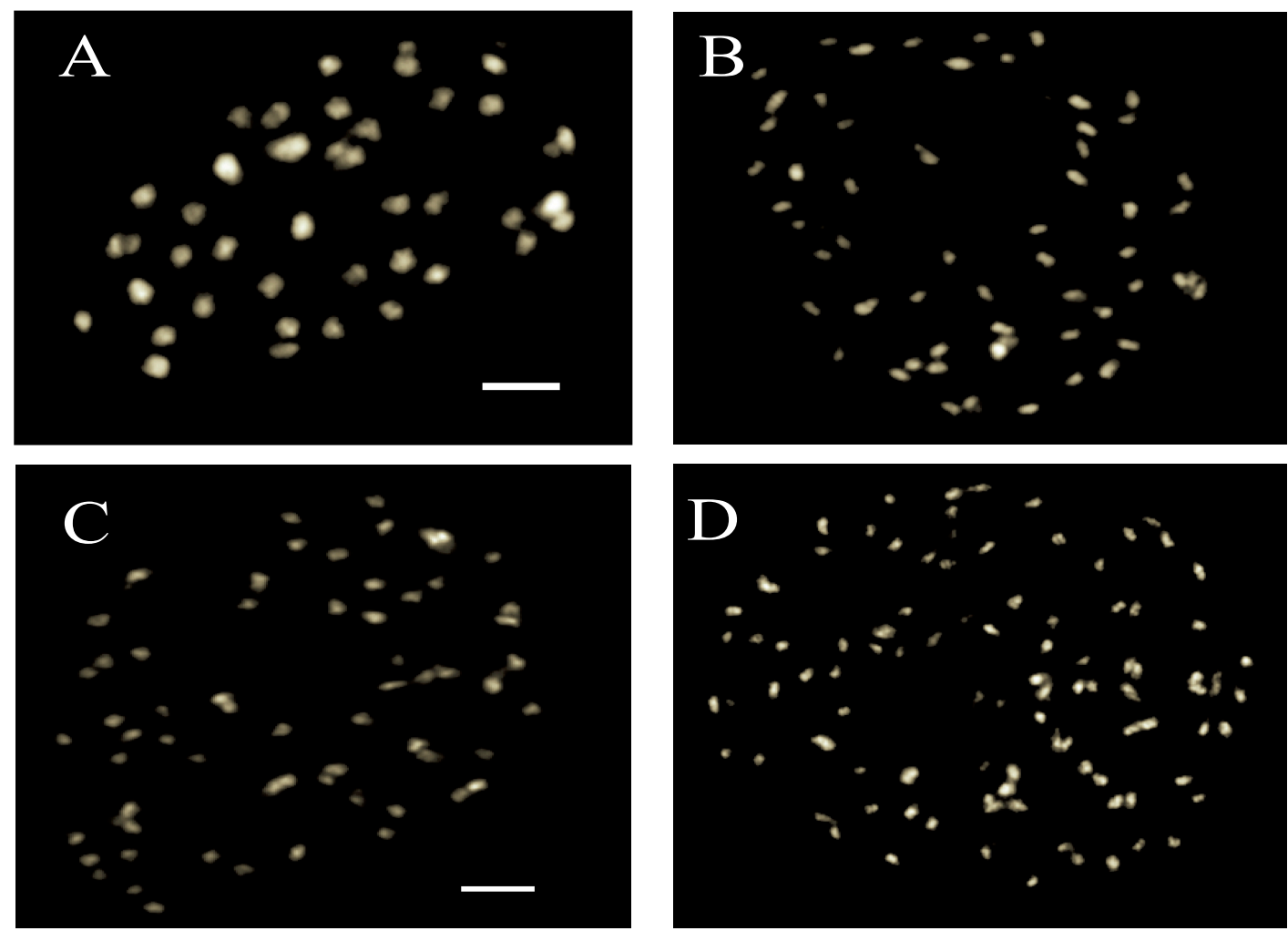

Figure 2. Mitotic metaphase chromosome spreads of $(\mathrm{A})$ D. rotundata $(\mathrm{TDr}-2763=2 \mathrm{n}=2 \mathrm{x}=40)$; (B) D. alata $(\mathrm{TDa}-1030=2 \mathrm{n}$ $=3 \mathrm{x}=60) ;(\mathbf{C})$ D. dumetorum $(\mathrm{TDd}-3778=2 \mathrm{n}=3 \mathrm{x}=60)$; and (D) D. esculenta (TDes-3038 = 2n = 4x = 80). Scale bar: $5 \mu \mathrm{m}$. 


\subsection{Flow Cytometry Analysis of Dioscorea Accessions}

Based on the peak positions of yam and CRBC nuclei on histograms of nuclear DNA amount, peak ratio was calculated for every accession (Table S1). The peaks for the estimation of nuclear DNA content for TDa-1124 (D. alata), TDb-3046 (D. bulbifera), TDd-3806 (D. dumetorum) and TDes-2786 (D. esculenta) relative to the peak for CRBC by flow cytometry are shown in Figure 3. The ratio of G1 peak position between yam and CRBC for D. rotundata accessions ranged from 0.53 (TDr-1585) to 0.76 (TDr-1489) in diploid accessions suggesting differences in genome sizes within these accessions, while, in triploid accessions, G1 peak ratio was 1.00. However, in TDr-1723 and TDr-3671, two diploid accessions based on chromosome counting and DArTseq data, the peak ratio was 1.00 (Table S1), indicating a disagreement between the results obtained from flow cytometry and chromosome counting as well as genotyping data.

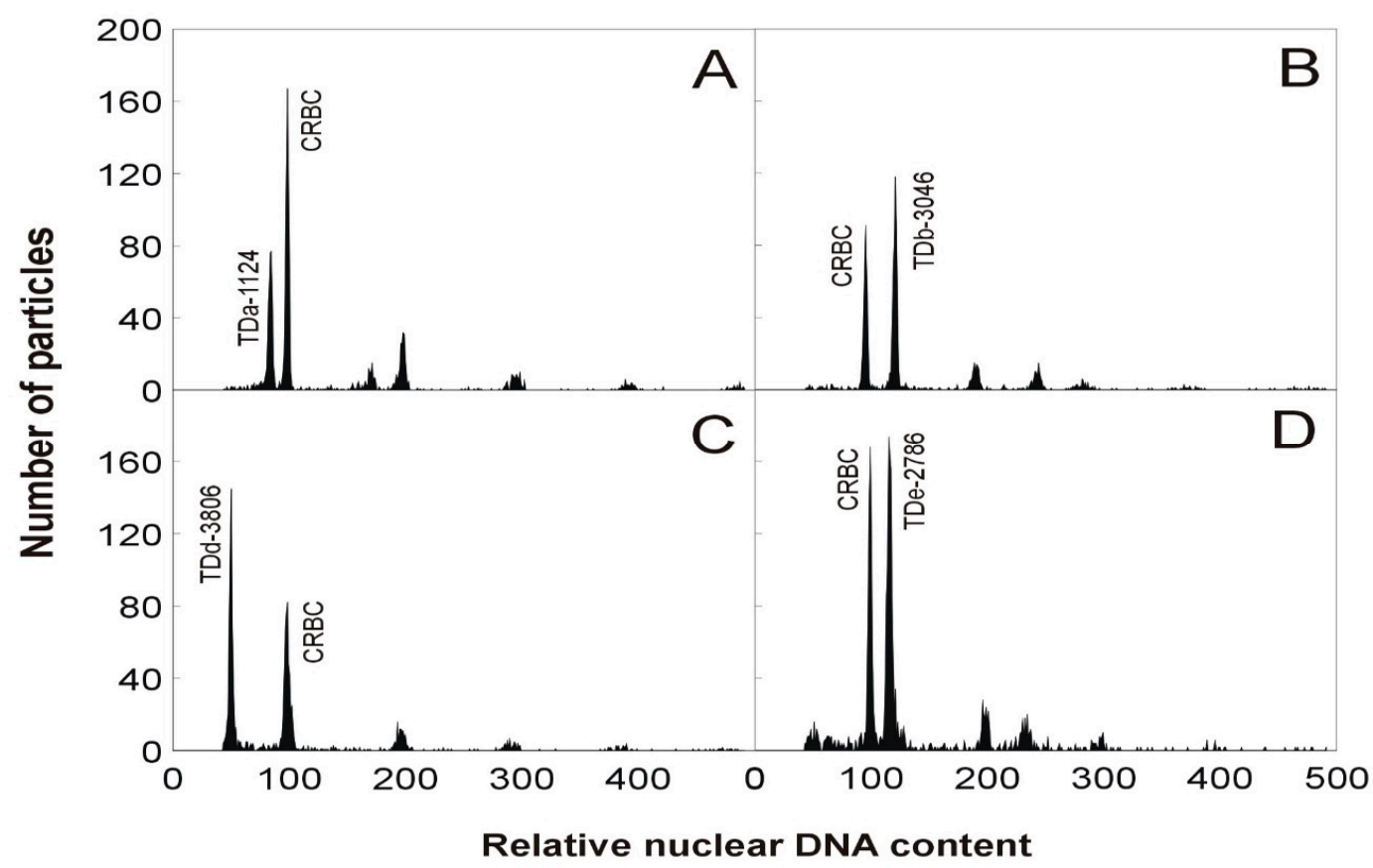

Figure 3. Histograms of relative nuclear DNA content obtained after simultaneous flow-cytometric analysis of DAPI-stained nuclei isolated from fresh leaf tissues of Dioscorea accessions and chicken red blood cell nuclei (CRBC). The gain of the instrument was adjusted so that the G1 peak of CRBC nuclei, which served as an internal reference standard, was positioned on channel 100. Peaks appearing on channels 200, 300, 400 and 500 correspond to doublets, triplets, etc. of CRBC nuclei. (A) Dioscorea alata (TDa-1124), peak ratio = 0.85; (B) D. bulbifera (TDb-3046), peak ratio = 1.27; (C) D. dumetorum (TDb-3806), peak ratio $=0.51 ;(\mathrm{D})$ D. esculenta $($ TDes-2786), peak ratio $=1$.

For D. alata, the ratio of yam/CRBC peak ratio in diploid accessions ranged from 0.48 (TDa-1471) to 0.61 (TDa-1196 and TDa-1287), while peak ratio in triploids ranged from 0.8 (TDa-1282) to 0.88 (TDa-1008) and for tetraploid accessions, the peak ratio ranged from 1.00 (TDa-1319) to 1.19 (TDa-1137) (Table S1). However, accessions TDa-1177 and TDa-1189, which were diploid and tetraploid, respectively based on chromosome counting and DArTseq data, had peak ratios of 0.88 and 0.51 , respectively indicating a discrepancy in the results obtained from flow cytometry and that of chromosome counting and genotyping data. Similarly, accession TDa-1014, which was diploid based on DArTseq data, had a peak ratio of 1.00 (Table S1). The results of TDa-1014 could not be confirmed through chromosome counting as the tuber of this accession did not germinate at IEB, Olomouc, Czech Republic. For D. cayenensis, two triploids and two tetraploids were observed based on chromosome counting and DArTseq analysis. Flow-cytometric analysis showed peak ratios of 1.00 and 1.33 to 1.38 , respectively, in those accessions (Table S1). 
Based on chromosome counting and DArTseq data, the D. dumetorum accessions were comprised of one diploid and five triploid accessions. Flow-cytometric analysis of nuclear DNA content gave peak ratio of 0.33 in diploid accession TDd-3909, while it ranged from 0.49 (TDd-4118) to 0.51 (TDd-3778 and TDd-3806) in the triploid accessions. All three D. esculenta accessions were tetraploids with 80 chromosomes, which were in agreement with the yam/CRBC peak ratio that ranged from 1.00 to 1.17. Similarly, all 16 D. bulbifera accessions were triploids based on chromosome counting and DArTseq data. Based on flow cytometry, the yam/CRBC peak ratio of one of these accessions was 0.73 , while that of the remaining 15 accessions ranged from 1.2 (TDb-3693) to 1.33 (TDb-3084). The results of majority of $D$. bulbifera accessions were in agreement between flow cytometry and chromosome counting as well as genotyping data.

For the two wild species, D. abyssinica and D. praehensilis, all six accessions were diploids based on chromosome counting (Table S1). The flow cytometric analysis resulted in peak ratios ranging from 0.67 (TDab-3884) to 0.73 (TDab-3847 and TDab-3881) in D. abyssinica, and 0.79 in the D. praehensilis accession.

\subsection{Ploidy Status and Phylogenetic Relationship of Dioscorea spp. Based on DArTseq SNP Markers}

All the accessions of cultivated Dioscorea spp. were genotyped using DArTseq for further analysis and assessment of genetic relationship among the accessions. The accessions were grouped into three main clusters (Figure 4). The first group comprised 82 accessions of $D$. alata, the second group had 6 accessions of D. dumetorum, 6 accessions of D. bulbifera, 4 accessions of $D$. cayenensis and 3 accessions of D. esculenta while the third and the largest group comprised 119 D. rotundata accessions (Figure 4). The third cluster with 119 D. rotundata accessions had two sub-groups, one consisting of $103(87 \%)$ accessions which are diploids and the other with 16 (13\%) accessions that are triploids (Table S1). However, some accessions did not cluster as expected based on their ploidy levels.

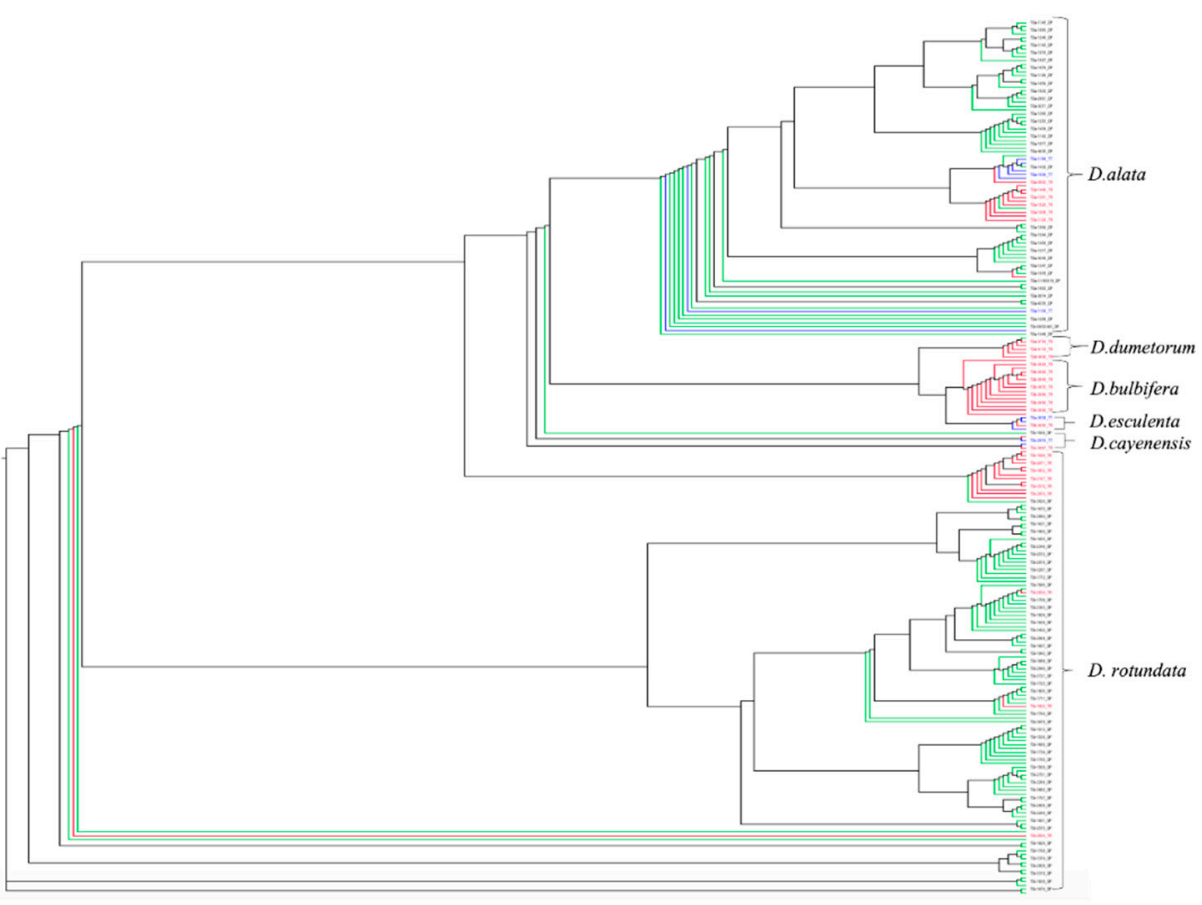

Figure 4. The phylogenetic tree constructed using DArTseq genotyping data on 230 cultivated Dioscorea spp. accessions and Neighbor-joining method to assess the genetic relationship among the accessions and different species and their ploidy levels. Green color $=$ diploid $(2 \mathrm{x})$, red color $=$ triploid $(3 \mathrm{x})$ and blue color $=$ tetraploid $(4 \mathrm{x})$. 


\section{Discussion}

Information on ploidy, in addition to providing insight into evolutionary history and relationships among cultivated crops and their wild relatives, is useful in designing strategies for genetic improvement. In the present study, we determined ploidy level by chromosome counting and flow cytometry-the two most widely used techniques, and compared values obtained with estimates from genotyping-based DArTseq data. Of the 236 accessions used in this study, discrepancies between the results obtained by chromosome counting and from cytometry were observed in only seven accessions $(0.029 \%)$. In other accessions ( $>97 \%$ ), the results of chromosome counting, and flow cytometry were in agreement, indicating that either of the two methods could be used for ploidy estimation. However, it may be advisable to confirm the results of flow cytometry through genotyping using DNA markers.

Dioscorea is one of the most difficult genera for cytogenetic and cytotaxonomic studies [45]. The chromosomes of Dioscorea spp. are small and dot-like, with their length ranging from 0.5 to $2.7 \mu \mathrm{m}$ at mitotic $\mathrm{C}$-metaphase stage $[9,15,46]$. Consequently, chromosome counting is difficult and time-consuming. In addition, the chromosomes often tend to clump together, thus making the counting process challenging [22]. Flow-cytometric estimation of nuclear DNA amounts has some important advantages over conventional chromosome counting [47]. The method is rapid, allowing screening of a large number of individuals in one day and does not require dividing cells [24,48]. For ploidy level determination using flow cytometry, it is, however, imperative to have a reference genotype/accession of the same species with already known ploidy [49]. An ideal standard should have a similar genome size as the sample species [49] and similar chromatin structure because the latter also affects DNA staining [50]. Since no internal standard/reference was available at the time this study was conducted, chicken erythrocyte nuclei from CRBC were used for this purpose. The yam/CRBC peak ratio obtained for different species in this study can be used in future rapid ploidy assessment studies in yams using flow cytometry. This approach has been successfully applied in banana [51,52] for large scale ploidy assessment. In addition, our study has identified, for the first time, based on agreement in ploidy number among the three methods used in the study viz. yam/CRBC peaks of the flow-cytometry method, chromosome number estimation through chromosome counting and genotyping through the DArTseq based technique, internal reference standards that can be used in future studies to determine the ploidy status in Dioscorea spp using flow cytometry alone.

In the flow cytometry procedure carried out in the present study, both the standard and sample nuclei were processed together before staining with DAPI. This fluorochrome preferentially binds to AT-rich DNA regions, a characteristic that accounts for its suitability for ploidy level estimations. Although flow cytometry is suitable for the determination of nuclear DNA content, we observed variation in relative fluorescence intensity, reflected in the range of yam/CRBC peak ratios within one ploidy level of a species (e.g., D. rotundata or D. alata accessions), an indication of variation in the nuclear DNA content. Such variation has been reported in many plant species, e.g., soybean [53] or banana [54,55]. Future studies on diversity and evolution of yams are required to address the issue of differences in nuclear DNA content among yam accessions of the same species and similar ploidy level. The internal standards identified for each Dioscorea spp. in this study will facilitate this considerably.

The majority of the D. rotundata accessions in the present study were diploids (89.1\%), results that are in agreement with the findings of an earlier study [56] that reported the segregation patterns of isozymes and SSRs in which most accessions of $D$. rotundata were found to have a basic chromosome number of $20(2 n=40)$. The preponderance of diploids $(78 \%)$ among the D. alata accessions in this study is also in agreement with the results of another study involving $110 \mathrm{D}$. alata accessions in which $76 \%$ had $2 n=40$ chromosomes [57]. In the latter study, $7 \%$ and $17 \%$ of the accessions were triploids and tetraploids, respectively, compared to $13 \%$ and $9 \%$ that were obtained in our study. Our results and those of these 
authors, together with the results of Bousalem et al. [58] on microsatellite segregation in four $D$. alata genotypes, are in agreement with respect to the basic chromosome number of water yam of $n=x=20$. There are very few reports on ploidy assessment in other cultivated and wild Dioscorea species. In the present study, all the accessions of D. bulbifera were triploids based on chromosome counting and DArTseq genotyping. The earlier studies using flow cytometry and chromosome counting reported the presence of tetraploids, pentaploids and hexaploids among D. bulbifera accessions [23,46]. Similarly, two triploids and two tetraploids were observed among the four D. cayenensis accessions in the current study, while Obidiegwu et al. [23] reported the presence of hexaploids and octaploids among $8 D$. cayenensis accessions. For $D$. dumetorum and D. esculenta, the majority of the accessions in the present study were triploids and tetraploids, respectively, while diploids were also observed among $D$. dumetorum accessions. Similar ploidy levels were observed by Obidiewu et al. [23] among these two species. The six accessions belonging to two wild species, D. abyssinica and D. praehensilis, assessed based on chromosome counting and flow cytometry, were diploids $(2 n=2 x=40)$, confirming the results of Gamiette et al. [15].

The DArTseq platform guarantees wide genomic coverage and is not affected by the limitations of meiotic chromosome pairing of hybrids in distant crosses [59]. Genotyping of the accessions of different yam species using the DArTseq platform would elucidate the genomic relationship between wild and cultivated species in yams. Such ploidy information from DArTseq based genotyping has been used to analyze the genomic relationships among diploid and polyploid species Triticeae [60]. Among studies on ploidy levels in yams to date, the present study used the highest number of accessions (236), which involved eight species that consisted of cultivated and wild types. In effect, the large number of accessions and multiple techniques used in our study offer the most up-to-date insight on ploidy in the Dioscorea and the reliability of the techniques for ploidy determination in the genus.

Based on the results from chromosome counting, flow cytometry and DArTseq genotyping, internal reference standards were identified for each Dioscorea spp. for future use in ploidy determination using flow cytometry. These accessions are D. rotundata (TDr1585 and TDr-1922), 14 of D. alata (TDa-1079, TDa-1083, TDa-1145, TDa-1187, TDa-1217, TDa-1240, TDa-1277, TDa-1319, TDa-1439, TDa-1471, TDa-2861, TDa-3271, TDa-4335 and TDa-4346) and one each of D. bulbifera (TDb-3692) and D. esculenta (TDes-3038) (Table S1). These internal standards are currently maintained at the Genetic Resources Center (GRC), IITA, Ibadan, Nigeria as field and in vitro collections.

\section{Conclusions}

Identifying the ploidy level of a given genotype is important for successful crossing. The findings in this study on ploidy assessment in yams are of significant value and will minimize failures in intra- and interspecific hybridization. Ploidy levels results based on flow cytometry, chromosome counting and DArTseq analyses were in agreement for two accessions of D. rotundata, 14 accessions of D. alata, one accession each of D. bulbifera and D. esculenta. These accessions are therefore useful as internal standards for future ploidy evaluation in yam. This is the first study that identified several accessions in Dioscorea spp. that can be used as internal standards for ploidy determination in yams.

Supplementary Materials: The following are available online at https: / www.mdpi.com/article / 10.3390/agronomy11101897/s1, Table S1: Relative nuclear DNA content, chromosome counts, and ploidy level determined based on DArTseq genotyping data on 236 accessions representing eight Dioscorea spp. and their geographical origin.

Author Contributions: R.B., J.D., V.A. and E.H. conceived and designed the study; D.D. and M.A. provided the planting materials; R.P. executed genotyping; C.G., L.S., A.N. and D.Š. performed the cytological analysis with the guidance of J.D., J.Č. and E.H.; C.G. and R.P. conducted molecular analysis; C.G. wrote the first draft of the manuscript with the guidance of G.B., R.A. and A.A. with inputs of other authors. All authors have read and agreed to the published version of the manuscript. 
Funding: This study was supported through a research grant to the International Institute of Tropical Agriculture (OPP1052998; AfricaYam Project) by the Bill and Melinda Gates Foundation. The scholarship was provided by the African Union Commission to the first author for his Ph.D. studies at The Pan African University Institute of Life and Earth Sciences (PAULESI), University of Ibadan, Nigeria. L.S., A.N., D.Š., E.H. and J.D. were supported by ERDF project 'Plants as a tool for sustainable global development' (No. CZ.02.1.01/0.0/0.0/16_019/0000827).

Institutional Review Board Statement: Not applicable.

Informed Consent Statement: Not applicable.

Data Availability Statement: All data have been submitted to YamBase portal (https:/ / yambase.org accessed on 11 November 2020), maintained at the International Institute of Tropical Agriculture, Ibadan, Nigeria.

Conflicts of Interest: All authors declare no conflict of interest.

\section{References}

1. Shen, L.; Xu, J.; Luo, L.; Hu, H.; Meng, X.; Li, X.; Chen, S. Predicting the potential global distribution of diosgenin-contained Dioscorea species. Chin. Med. 2018, 13, 58. [CrossRef] [PubMed]

2. Sonibare, M.A.; Asiedu, R.; Albach, D.C. Genetic diversity of Dioscorea dumetorum (Kunth) Pax using amplified fragment length polymorphisms (AFLP) and cpDNA. Biochem. Syst. Ecol. 2010, 38, 320-334. [CrossRef]

3. Darkwa, K.; Olasanmi, B.; Asiedu, R.; Asfaw, A. Review of empirical and emerging breeding methods and tools for yam (Dioscorea spp.) improvement: Status and prospects. Plant Breed. 2020, 139, 474-497. [CrossRef]

4. Asiedu, R.; Sartie, A. Crops that feed the world 1. Yams: Yams for income and food security. Food Secur. 2010, 2, 305-315. [CrossRef]

5. Price, E.J.; Bhattacharjee, R.; Lopez-Montes, A.; Fraser, P.D. Metabolite profiling of yam (Dioscorea spp.) accessions for use in crop improvement programmes. Metabolomics 2017, 13, 1-12. [CrossRef]

6. FAO. Food and Agriculture Organization of the United Nations Statistics Database, FAOSTAT. 2017. Available online: http: //www.fao.org/faostat/en/\#data/QC (accessed on 10 March 2020).

7. Alabi, T.R.; Adebola, P.O.; Asfaw, A.; De Koeyer, D.; Lopez-Montes, A.; Asiedu, R. Spatial multivariate cluster analysis for defining target population of environments in West Africa for yam breeding. Int. J. Appl. Geospa. Res. 2019, 10, 1-30. [CrossRef]

8. Baimey, H.; Coyne, D.; Labuschagne, N. Effect of fertiliser application on yam nematode (Scutellonema bradys) multiplication and consequent damage to yam (Dioscorea spp.) under field and storage conditions in Benin. Int. J. Pest Manag. 2006, 52, 63-70. [CrossRef]

9. Mignouna, H.D.; Abang, M.M.; Asiedu, R. Genomics of yams, a common source of food and medicine in the tropics. Gen. Trop. Crop Plants. 2008, 549-570. [CrossRef]

10. Girma, G.; Natsume, S.; Carluccio, A.V.; Takagi, H.; Matsumura, H.; Uemura, A.; Muranaka, S.; Takagi, H.; Stavolone, L.; Gedil, M.; et al. Identification of candidate flowering and sex genes in white Guinea yam (D. rotundata Poir.) by SuperSAGE transcriptome profiling. PLoS ONE 2019, 14, e0216912. [CrossRef] [PubMed]

11. Siadjeu, C.; Pucker, B.; Viehöver, P.; Albach, D.C.; Weisshaar, B. High contiguity de novo genome sequence assembly of Trifoliate yam (Dioscorea dumetorum) using long read sequencing. Genes 2020, 11, 274. [CrossRef] [PubMed]

12. Girma, G.; Hyma, K.E.; Asiedu, R.; Mitchell, S.E.; Gedil, M.; Spillane, C. Next generation sequencing based genotyping, cytometry and phenotyping for understanding diversity and evolution of guinea yams. Theor. Appl. Genet. 2014, 127, 1783-1794. [CrossRef]

13. Pickering, R.A.; Hayes, J.D. Partial incompatibility in crosses between Hordeum vulgare L. and H. bulbosum L. Euphytica 1976, 25, 671-678. [CrossRef]

14. Abraham, K.; Nair, P.G. Polyploidy and sterility in relation to sex in Dioscorea alata L. (Dioscoreaceae). Genetica 1991, 83, 93-97. [CrossRef]

15. Gamiette, F.; Bakry, F.; Ano, G. Ploidy determination of some yam species (Dioscorea spp.) by flow cytometry and conventional chromosomes counting. Genet. Resour. Crop Evol. 1999, 46, 19-27. [CrossRef]

16. Egesi, C.N.; Pillay, M.; Asiedu, R.; Egunjobi, J.K. Ploidy analysis in water yam, Dioscorea alata L. germplasm. Euphytica 2002, 128, 225-230. [CrossRef]

17. Sattler, M.C.; Carvalho, C.R.; Clarindo, W.R. The polyploidy and its key role in plant breeding. Planta 2016, 243, 281-296. [CrossRef]

18. Malapa, R.; Arnau, G.; Noyer, J.L.; Lebot, V. Genetic diversity of the greater yam (Dioscorea alata L.) and relatedness to D. nummularia Lam. and D. transversa Br. as revealed with AFLP markers. Genet. Resour. Crop Evol. 2005, 52, 919-929. [CrossRef]

19. Arnau, G.; Abraham, K.; Sheela, M.N.; Chair, H.; Sartie, A.; Asiedu, R. Yams. Root and Tuber Crops. In Handbook of Plant Breeding; Springer: New York, NY, USA, 2010; Volume 7, pp. 127-148.

20. Zlesak, D.C. Pollen diameter and guard cell length as predictors of ploidy in diverse rose cultivars, species and breeding lines. J. Floric. Ornam. Biotech. 2009, 3, 53-70. 
21. Chambers, A.H.; Pollard, H.; Folta, K.M. Limitations of morphological ploidy estimation methods in Fragaria. J. Berry Res. 2013, 3 , 135-149. [CrossRef]

22. Dansi, A.; Mignouna, H.D.; Pillay, M.; Zok, S. Ploidy variation in the cultivated yams (Dioscorea cayenensis-Dioscorea rotundata complex) from Cameroon as determined by flow cytometry. Euphytica 2001, 119, 301-307. [CrossRef]

23. Obidiegwu, J.; Rodriguez, E.; Ene-Obong, E.; Loureiro, J.; Muoneke, C.; Santos, C.; Kolesnikova-Allen, M.; Asiedu, R. Ploidy levels of Dioscorea alata L. germplasm determined by flow cytometry. Genet. Resour. Crop Evol. 2010, 57, 351-356. [CrossRef]

24. Suda, J.; Trávníček, P. Reliable DNA ploidy determination in dehydrated tissues of vascular plants by DAPI flow cytometry-new prospects for plant research. Cytom. Part A 2006, 69, 273-280. [CrossRef]

25. Delaat, A.M.M.; Gohde, W.; Vogelzakg, M.J.D.C. Determination of ploidy of single plants and plant populations by flow cytometry. Plant Breed. 1987, 99, 303-307. [CrossRef]

26. Dolezel, J. Application of flow cytometry for the study of plant genomes. J. Appl. Genet. 1997, 3, $285-302$.

27. Besnard, G.; Baali-Cherif, D. Coexistence of diploids and triploids in a Saharan relict olive: Evidence from nuclear microsatellite and flow cytometry analyses. C. R. Biol. 2009, 332, 1115-1120. [CrossRef]

28. Nemorin, A.; David, J.; Maledon, E.; Nudol, E.; Dalon, J.; Arnau, G. Microsatellite and flow cytometry analysis to help understand the origin of Dioscorea alata polyploids. Ann. Bot. 2013, 112, 811-819. [CrossRef] [PubMed]

29. Donkpegan, A.S.L.; Doucet, J.-L.; Dainou, K.; Hardy, O.J. Microsatellite development and flow cytometry in the African tree genus Afzelia (Fabaceae, Caesalpinioideae) reveal a polyploid complex. Appl. Plant Sci. 2015, 3, 1400097. [CrossRef]

30. Viruel, J.; Conejero, M.; Hidalgo, O.; Pokorny, L.; Powell, R.F.; Forest, F.; Kantar, M.B.; Soto Gomez, M.; Graham, S.W.; Gravendeel, B.; et al. A target capture-based method to estimate ploidy from herbarium specimens. Front. Plant Sci. 2019, 10, 937. [CrossRef] [PubMed]

31. Gardina, P.J.; Lo, K.C.; Lee, W.; Cowell, J.K.; Turpaz, Y. Ploidy status and copy number aberrations in primary glioblastomas defined by integrated analysis of allelic ratios, signal ratios and loss of heterozygosity using 500K SNP Mapping Arrays. BMC Genom. 2008, 9, 1-16. [CrossRef]

32. Rungis, D.E.; Voronova, A.; Kokina, A.; Veinberga, I.; Skrabule, I.; Rostoks, N. Assessment of genetic diversity and relatedness in the Latvian potato genetic resources collection by DArT genotyping. Plant Genet. Resour. 2017, 15, 72-78. [CrossRef]

33. Gatarira, C.; Paterne, A.; Matsumoto, R.; Edemondu, A.; Adetimirin, V.; Bhattacharjee, R.; Asiedu, R.; Asfaw, A. Genome-wide association analysis for tuber dry matter and oxidative browning in water yam (Dioscorea alata L.). Plants 2020, 9, 969. [CrossRef]

34. Doležel, J.; Greilhuber, J.; Suda, J. Estimation of nuclear DNA content in plants using flow cytometry. Nat. Protoc. 2007, 2, 2233. [CrossRef]

35. Otto, F. DAPI staining of fixed cells for high-resolution flow cytometry of nuclear DNA. Methods Cell Biol. 1990, 33, 105-110.

36. Galbraith, D.W.; Lambert, G.M.; Macas, J.; Dolezel, J. Analysis of nuclear DNA content and ploidy in higher plants. Curr. Protoc. Cytom. 1997, 2, 7.6.1-7.6.22. [CrossRef]

37. Porebski, S.; Bailey, L.G.; Baum, B.R. Modification of a CTAB DNA extraction protocol for plants containing high polysaccharide and polyphenol components. Plant Mol. Biol. Rep. 1997, 15, 8-15. [CrossRef]

38. Kilian, A.; Wenzl, P.; Huttner, E.; Carling, J.; Xia, L.; Blois, H.; Caig, V.; Heller-Uszynska, K.; Jaccoud, D.; Hopper, C.; et al. Diversity arrays technology: A generic genome profiling technology on open platforms. In Data Production and Analysis in Population Genomics; Humana Press: Totowa, NJ, USA, 2012; pp. 67-89.

39. Bradbury, P.J.; Zhang, Z.; Kroon, D.E.; Casstevens, T.M.; Ramdoss, Y.; Buckler, E.S. TASSEL: Software for association mapping of complex traits in diverse samples. Bioinformatics 2007, 23, 2633-2635. [CrossRef]

40. Gompert, Z.; Mock, K.E. Detection of individual ploidy levels with genotyping-by-sequencing (GBS) analysis. Mol. Ecol. Resour. 2017, 17, 1156-1167. [CrossRef] [PubMed]

41. Chang, C.C.; Chow, C.C.; Tellier, L.C.; Vattikuti, S.; Purcell, S.M.; Lee, J.J. Second-generation PLINK: Rising to the challenge of larger and richer datasets. GigaScience 2015, 4, 7. [CrossRef]

42. Purcell, S.; Neale, B.; Todd-Brown, K.; Thomas, L.; Ferreira, M.A.; Bender, D.; Maller, J.; Sklar, P.; De Bakker, P.I.; Daly, M.J. PLINK: A tool set for whole-genome association and population-based linkage analyses. Am. J. Hum. Genet. 2007, 81, 559-575. [CrossRef] [PubMed]

43. Tamura, K.; Stecher, G.; Peterson, D.; Filipski, A.; Kumar, S. MEGA6: Molecular evolutionary genetics analysis version 6.0. Mol. Biol. Evol. 2013, 30, 2725-2729. [CrossRef] [PubMed]

44. R Core Team. R: A Language and Environment for Statistical Computing; R Core Team: Vienna, Austria, 2018.

45. Bhattacharjee, R.; Gedil, M.; Sartie, A.; Otoo, E.; Dumet, D.; Kikuno, H.; Kumar, P.L.; Asiedu, R. Dioscorea. In Wild Crop Relatives: Genomic and Breeding Resources; Springer: Berlin/Heidelberg, Germany, 2011; pp. 71-96.

46. Norman, P.E.; Tongoona, P.; Shanahan, P.E. Diversity in chromosome number and raphide morphology of yam (Dioscorea spp.) genotypes from Sierra Leone. Afr. J. Plant. Sci. 2011, 6, 157-160.

47. Roux, N.; Toloza, A.; Radecki, Z.; Zapata-Arias, F.J.; Dolezel, J. Rapid detection of aneuploidy in Musa using flow cytometry. Plant Cell Rep. 2003, 21, 483-490. [CrossRef] [PubMed]

48. Doležel, J.; Lysák, M.A.; Van den Houwe, I.; Dolezelová, M.; Roux, N. Use of flow cytometry for rapid ploidy determination in Musa species. Infomusa 1997, 6, 6-9.

49. Praça-Fontes, M.M.; Carvalho, C.R.; Clarindo, W.R.; Cruz, C.D. Revisiting the DNA C-values of the genome size-standards used in plant flow cytometry to choose the "best primary standards". Plant Cell Rep. 2011, 30, 1183-1191. [CrossRef] 
50. Doležel, J.; Bartoš, J. Plant DNA flow cytometry and estimation of nuclear genome size. Ann. Bot. 2005, 95, 99-110. [CrossRef] [PubMed]

51. Dolezelová, M.; Doležel, J.; Roux, N.; Swennen, R. Ploidy levels revealed. InfoMusa 2005, 14, 34-36.

52. Christelová, P.; De Langhe, E.; Hřibová, E.; Čížková, J.; Sardos, J.; Hušáková, M.; Sutanto, A.; Kepler, A.K.; Swennen, R.; Roux, N.; et al. Molecular and cytological characterization of the global Musa germplasm collection provides insights into the treasure of banana diversity. Biodivers. Conserv. 2017, 26, 801-824. [CrossRef]

53. Rayburn, A.L.; Birdar, D.P.; Bullock, D.G.; Nelson, R.L.; Gourmet, C.; Wetzel, J.B. Nuclear DNA content diversity in Chinese soybean introductions. Ann. Bot. 1997, 80, 321-325. [CrossRef]

54. Bartoš, J.; Alkhimova, O.; Doleželová, M.; De Langhe, E.; Doležel, J. Nuclear genome size and genomic distribution of ribosomal DNA in Musa and Ensete (Musaceae): Taxonomic implications. Cytogenet. Genome Res. 2005, 109, 50-57. [CrossRef] [PubMed]

55. Č́ižková, J.; Hřibová, E.; Humplíková, L.; Christelová, P.; Suchánková, P.; Doležel, J. Molecular analysis and genomic organization of major DNA satellites in banana (Musa spp.). PLoS ONE 2013, 8, e54808. [CrossRef]

56. Scarcelli, N.; Daïnou, O.; Agbangla, C.; Tostain, S.; Pham, J.L. Segregation patterns of isozyme loci and microsatellite markers show the diploidy of African yam Dioscorea rotundata $(2 \mathrm{n}=40)$. Theor. Appl. Genet. 2005, 111, 226-232. [CrossRef] [PubMed]

57. Arnau, G.; Némorin, A.; Maledon, E.; Abraham, K. Revision of ploidy status of Dioscorea alata L. (Dioscoreaceae) by cytogenetic and microsatellite segregation analysis. Theor. Appl. Genet. 2009, 118, 1239-1249. [CrossRef] [PubMed]

58. Bousalem, M.; Arnau, G.; Hochu, I.; Arnolin, R.; Viader, V.; Santoni, S.; David, J. Microsatellite segregation analysis and cytogenetic evidence for tetrasomic inheritance in the American yam Dioscorea trifida and a new basic chromosome number in the Dioscoreacae. Theor. Appl. Genet. 2006, 113, 439-451. [CrossRef] [PubMed]

59. Seberg, O.; Petersen, G. A critical review of concepts and methods used in classical genome analysis. Bot. Rev. 1998, 64, $372-417$. [CrossRef]

60. Edet, O.U.; Gorafi, Y.S.; Nasuda, S.; Tsujimoto, H. DArTseq-based analysis of genomic relationships among species of tribe Triticeae. Sci. Rep. 2018, 8, 1-11. 